\title{
Surgical correction of ptosis in ocular fibrosis syndrome
}

\author{
Christopher Liu, Rita Ohri, Giovanni Frongia, Richard Collin
}

\begin{abstract}
The surgical management of ptosis is reported in seven patients suffering from the ocular fibrosis syndrome. Satisfactory results were obtained with bilateral Crawford type brow suspension with autologous fascia lata in six patients and bilateral Fox type brow suspension with stored fascia lata in a young child. As patients with ocular fibrosis syndrome usually exhibit little or no Bell's phenomenon, corneal exposure can become a problem after brow suspension. It was recommended that the lids are left just closed on the operating table at the end of the operation. None of the patients required a subsequent procedure to lower an overcorrection of the ptosis. The routine prescription of ocular lubricants for 2 months after ptosis correction is advocated. Urgent brow suspension in young children using nonautologous materials should only be considered if there is a risk of amblyopia.

(Brf Ophthalmol 1994; 78: 271-274)
\end{abstract}

Eye Hospital, City Road,

London

C Liu

R Ohri

G Frongia

$\mathrm{R}$ Collin

Correspondence to:

Mr C S C Liu, Department of

Ophthalmology,

Addenbrooke's Hospital, Hills

Road, Cambridge CB2 2QQ.

Accepted for publication

3 November 1993

Generalised fibrosis syndrome of the extraoc muscles (also known as the ocular fibrosis syndrome, ${ }^{1}$ congenital fibrosis of the extraocular muscles, ${ }^{2-5}$ and exaggerated A-pattern ${ }^{6}$ ) is a rare, ${ }^{7}$ congenital anomaly of unknown aetiology affecting the extraocular muscles and their fascial sheaths. The syndrome may occasionally be familial when transmission is autosomal dominant. ${ }^{1489}$ The anomaly is characterised by normal extraocular muscle tissues being replaced by primary fibrosis leading to a mechanical restriction of eye movements accompanied by ptosis. ${ }^{457910}$ The eyes are in a hypotropic position to a varying degree because the inferior rectus muscles are the most severely involved..$^{459}$ The patient adopts a head posture with chin elevation. ${ }^{4579}$ The diagnosis is made clinically from the unique eye movement pattern, the presence of ptoses, and is confirmed by a positive forced duction test. ${ }^{9}$

Since there is minimal or no levator function in these patients, ${ }^{7}$ the choice of surgical procedure for the correction of ptosis is limited. Ideally, any extraocular muscle surgery to align the eyes in as near the primary position as possible for the elimination of chin elevation should be completed before ptosis surgery is considered. ${ }^{7} \mathrm{We}$ undertook ptosis surgery on seven patients with ocular fibrosis syndrome in whom other causes for squint and ptosis had been excluded (for example, brain stem anomaly, third nerve palsies, etc).

\section{Patients and methods}

We carried out bilateral ptosis surgery in seven patients with ocular fibrosis syndrome. There were six females and one male. The average age at

Table 1 Patient characteristics

\begin{tabular}{|c|c|c|c|c|c|c|c|c|c|c|c|c|c|}
\hline \multirow{2}{*}{$\begin{array}{l}\text { Case } \\
\text { No }\end{array}$} & \multirow{2}{*}{$\begin{array}{l}\text { Age at } \\
\text { presentation } \\
\text { (years) }\end{array}$} & \multirow[b]{2}{*}{ Sex } & \multirow{2}{*}{$\begin{array}{l}\text { Presenting } \\
\text { complaint }\end{array}$} & \multirow{2}{*}{$\begin{array}{l}\text { Family } \\
\text { history }\end{array}$} & \multirow{2}{*}{$\begin{array}{l}\text { No of procedures } \\
\text { for strabismus and } \\
\text { ptosis before } \\
\text { presentation }\end{array}$} & \multirow{2}{*}{$\begin{array}{l}\text { Further } \\
\text { procedures } \\
\text { planned for } \\
\text { strabismus }\end{array}$} & \multicolumn{2}{|c|}{$\begin{array}{l}\text { Ptosis: } \\
\text { palpebral } \\
\text { aperture }(\mathrm{mm})\end{array}$} & $\begin{array}{l}\text { Ptosis: skin } \\
\text { crease }(\mathrm{mm})\end{array}$ & \multicolumn{2}{|c|}{$\begin{array}{l}\text { Ptosis: levator } \\
\text { function }(\mathrm{mm})\end{array}$} & \multirow{2}{*}{$\begin{array}{l}\text { Frontalis } \\
\text { overaction }\end{array}$} & \multirow{2}{*}{$\begin{array}{l}\text { Bell's } \\
\text { phenomenon }\end{array}$} \\
\hline & & & & & & & $R$ & $L$ & $R$ & $R$ & $L$ & & \\
\hline 1 & 2 & $M$ & $\begin{array}{l}\text { Bilateral } \\
\text { congenital } \\
\text { ptoses; bumping } \\
\text { into things }\end{array}$ & $\begin{array}{l}\text { Brother } \\
\text { mother }\end{array}$ & $\begin{array}{l}\text { Bilateral IR recession } \\
6 \text { months after ptosis } \\
\text { surgery }\end{array}$ & None & $2-3$ & $2-3$ & None & \multicolumn{2}{|c|}{ Very poor } & Marked & $?$ \\
\hline 2 & 17 & $\mathrm{~F}$ & $\begin{array}{l}\text { Eyelid levels } \\
\text { getting lower } \\
\text { interfering with } \\
\text { vision }\end{array}$ & None & $\begin{array}{l}\text { Bilateral Everbush } \\
\text { (ptosis surgery) as } \\
\text { small child }\end{array}$ & None & 3 & 3 & None & \multicolumn{2}{|l|}{ None } & Marked & Poor \\
\hline 3 & $1 \mathrm{yr} 4 \mathrm{mths}$ & $\mathrm{F}$ & $\begin{array}{l}\text { Bilateral ptosis; } \\
\text { strabismus }\end{array}$ & None & $\begin{array}{l}2 \text { previous } \\
\text { strabismus } \\
\text { procedures }\end{array}$ & None & 5 & 6 & None & $<1$ & $<1$ & Marked & None \\
\hline 4 & 10 & $\mathrm{~F}$ & $\begin{array}{l}\text { Couldn't see } \\
\text { through ptotic } \\
\text { lids and lashes; } \\
\text { problems with } \\
\text { ball games at } \\
\text { school }\end{array}$ & None & $\begin{array}{l}\text { procedures } \\
1 \text { previous } \\
\text { strabismus } \\
\text { procedure }\end{array}$ & None & 3 & 3 & None & \multicolumn{2}{|l|}{ None } & Marked & None \\
\hline 5 & 5 & $\mathbf{F}$ & Bilateral ptosis & None & $\begin{array}{l}1 \text { previous } \\
\text { strabismus } \\
\text { procedure }\end{array}$ & None & 6 & 6 & 6 & \multicolumn{2}{|l|}{ None } & Marked & None \\
\hline $6^{\star}$ & 24 & $\mathbf{F}$ & $\begin{array}{l}\text { Lids dropping } \\
\text { again }\end{array}$ & $\begin{array}{l}\text { Strong } \\
\text { family } \\
\text { history }\end{array}$ & $\begin{array}{l}2 \times \text { strabismus ops. } \\
\text { Bilateral ptosis } \\
\text { surgery at } 16 \text { years }\end{array}$ & $\begin{array}{l}\text { Awaiting } \\
\text { correction } \\
\text { of } \mathrm{L} \\
\text { exotropia }\end{array}$ & 8 & 6 & $\begin{array}{l}\text { Incomplete } \\
(4) \quad(6)\end{array}$ & 1 to 2 & 1 & Marked & Poor \\
\hline $7^{\star}$ & 22 & $F$ & Bilateral ptosis & $\begin{array}{l}\text { Strong } \\
\text { family } \\
\text { history }\end{array}$ & $\begin{array}{l}1 \text { previous } \\
\text { strabismus } \\
\text { procedure }\end{array}$ & None & 5 & 5 & $\begin{array}{l}\text { Hint of skin } \\
\text { crease at } \\
\text { (5) }\end{array}$ & \multicolumn{2}{|l|}{ None } & Marked & Poor \\
\hline
\end{tabular}


Table 2 Type of surgery and results

\begin{tabular}{|c|c|c|c|c|c|c|c|c|c|c|c|c|}
\hline \multirow{2}{*}{$\begin{array}{l}\text { Case } \\
\text { No }\end{array}$} & \multirow[b]{2}{*}{ Indication(s) } & \multirow{2}{*}{$\begin{array}{l}\text { Age at } \\
\text { surgery } \\
\text { (years) }\end{array}$} & \multirow{2}{*}{$\begin{array}{l}\text { Type of } \\
\text { surgery (all } \\
\text { bilateral) }\end{array}$} & \multirow[b]{2}{*}{ Material } & \multicolumn{2}{|c|}{$\begin{array}{l}\text { Result: } \\
\text { palpebral } \\
\text { aperture (in mm) } \\
\text { (Pre-op) }\end{array}$} & \multicolumn{2}{|c|}{$\begin{array}{l}\text { Result: skin } \\
\text { crease }(\mathrm{mm})\end{array}$} & \multirow{2}{*}{$\begin{array}{l}\text { Result: chin } \\
\text { elevation }\end{array}$} & \multirow{2}{*}{$\begin{array}{l}\text { Result: } \\
\text { complications }{ }^{\star} \\
\text { (including corneal } \\
\text { exposure) }\end{array}$} & \multirow{2}{*}{$\begin{array}{l}\text { Result: patient } \\
\text { satisfaction }\end{array}$} & \multirow{2}{*}{$\begin{array}{l}\text { Follow } \\
\text { up } \\
\text { (months) }\end{array}$} \\
\hline & & & & & $R$ & $L$ & $R$ & $L$ & & & & \\
\hline 1 & $\begin{array}{l}\text { Amblyopia } \\
\text { despite occlusion }\end{array}$ & 2 & $\begin{array}{l}\text { Fox brow } \\
\text { suspension }\end{array}$ & $\begin{array}{l}\text { Stored fascia } \\
\text { lata }\end{array}$ & $\begin{array}{l}7 \\
(2-3)\end{array}$ & $\begin{array}{l}5 \\
(2-3)\end{array}$ & Good & None & $\begin{array}{l}\text { Moderate } \\
\text { residual chin } \\
\text { elevation }\end{array}$ & Lid asymmetry & $\begin{array}{l}\text { No longer falling } \\
\text { over and } \\
\text { bumping into } \\
\text { things }\end{array}$ & 15 \\
\hline 2 & Cosmesis; vision & 18 & $\begin{array}{l}\text { Crawford } \\
\text { brow } \\
\text { suspension }\end{array}$ & $\begin{array}{l}\text { Autogenous } \\
\text { fascia lata }\end{array}$ & $\begin{array}{l}7 \\
(3)\end{array}$ & $\begin{array}{c}5 \\
(3)\end{array}$ & \multicolumn{2}{|c|}{ Not recorded } & Much reduced & $\begin{array}{l}\text { Leg hernia; on } \\
\text { the brink of } \\
\text { corneal exposure }\end{array}$ & Patient pleased & 6 \\
\hline 3 & $\begin{array}{l}\text { Cosmesis; head } \\
\text { posture }\end{array}$ & $4 \cdot 5$ & $\begin{array}{l}\text { Crawford } \\
\text { brow } \\
\text { suspension }\end{array}$ & $\begin{array}{l}\text { Autogenous } \\
\text { fascia lata }\end{array}$ & $\begin{array}{l}6-7 \\
(5)\end{array}$ & $\begin{array}{l}8-9 \\
(6)\end{array}$ & 5 & 5 & No head posture & None & $\begin{array}{l}\text { Parents pleased; } \\
\text { good cosmesis }\end{array}$ & 22 \\
\hline 4 & $\begin{array}{l}\text { Couldn't see } \\
\text { through ptotic } \\
\text { lids and lashes; } \\
\text { problems with } \\
\text { ball games at } \\
\text { school }\end{array}$ & 12 & $\begin{array}{l}\text { Crawford } \\
\text { brow } \\
\text { suspension }\end{array}$ & $\begin{array}{l}\text { Autogenous } \\
\text { fascia lata }\end{array}$ & $\begin{array}{l}6 \\
(3)\end{array}$ & $\begin{array}{l}7 \\
(3)\end{array}$ & \multicolumn{2}{|c|}{ None } & Much reduced & None & $\begin{array}{l}\text { Seeing better; } \\
\text { performance } \\
\text { with ball games } \\
\text { improved }\end{array}$ & 4 \\
\hline 5 & Cosmesis & 6.5 & $\begin{array}{l}\text { Crawford } \\
\text { brow } \\
\text { suspension }\end{array}$ & $\begin{array}{l}\text { Autogenous } \\
\text { fascia lata }\end{array}$ & $\begin{array}{l}6 \\
(6)\end{array}$ & $\begin{array}{l}6 \\
(6)\end{array}$ & 5 & 5 & Much reduced & $\begin{array}{l}\text { Mild left corneal } \\
\text { stain }\end{array}$ & $\begin{array}{l}\text { Father happy } \\
\text { with appearance }\end{array}$ & 9 \\
\hline 6 & Cosmesis & 25 & $\begin{array}{l}\text { Crawford } \\
\text { brow } \\
\text { suspension }\end{array}$ & $\begin{array}{l}\text { Autogenous } \\
\text { fascia lata }\end{array}$ & $\begin{array}{c}8 \\
(8)\end{array}$ & $\begin{array}{l}8 \\
(6)\end{array}$ & 4 & 6 & Much reduced & $\begin{array}{l}\mathrm{R}<\mathrm{L} \\
\text { lagophthamos; } \\
\text { left corneal stain }\end{array}$ & Patient pleased & 11 \\
\hline 7 & Cosmesis & $22 \cdot 5$ & $\begin{array}{l}\text { Crawford } \\
\text { brow } \\
\text { suspension }\end{array}$ & $\begin{array}{l}\text { Autogenous } \\
\text { fascia lata }\end{array}$ & $\begin{array}{c}9 \\
(5)\end{array}$ & $\begin{array}{l}9 \\
(5)\end{array}$ & \multicolumn{2}{|c|}{ Not recorded } & Much reduced & None & Patient pleased & 5 \\
\hline
\end{tabular}

All cases were done under general anaesthesia. In all cases there was much reduced frontalis overaction following brow suspension. None of the patients required further eyelid surgery for postoperative corneal exposure.

presentation was 11.62 years (range 16 months to 24 years). The presenting complaint, family history, surgical history, and further surgery planned for strabismus and ptosis and the preoperative assessment of ptosis are summarised in Table 1. Since all the patients effectively had no levator function, they all underwent brow suspension ptosis operations.

The indication(s) for ptosis surgery, the age at which surgery was carried out, the type of surgery and material used, the result of ptosis surgery including complications and patient satisfaction, and the follow up period are summarised in Table 2 .

\section{Results}

We achieved satisfactory results in all seven patients (Figs 1 to 4 ). All the patients found it

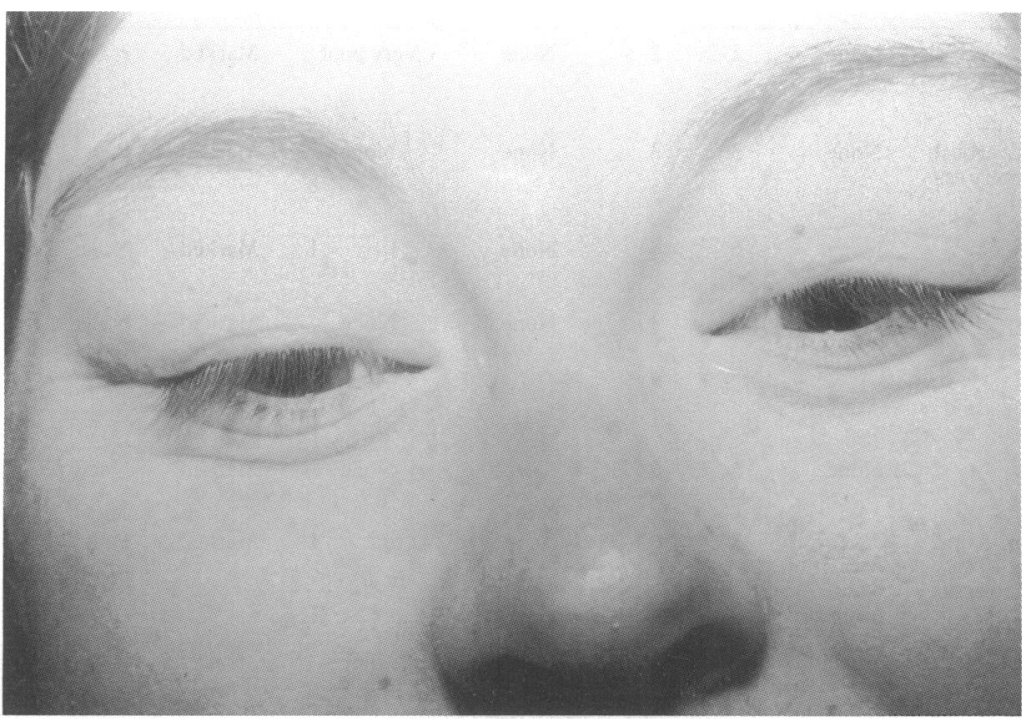

Figure 1 Preoperative photograph of a patient with ocular fibrosis syndrome demonstrating bilateral ptosis despite marked frontalis overaction and virtually no skin creases. less of an effort to open their eyes postoperatively. The palpebral apertures of six patients widened after surgery. Case 5 had palpebral apertures of $6 \mathrm{~mm}$ in each eye both before and after brow suspension, but had good skin creases postoperatively as had the other patients and she was happy with the result. Skin creases have the effect of improving cosmesis as patients 'look more awake' (Fig 2). Five patients had their chin elevation head posture much reduced. One had no awkward head posture and one had moderate residual chin elevation. Three patients developed mild corneal exposure but were controlled with simple lubricant ointment at night. One patient developed a leg hernia which healed after some months. One patient had asymmetrical lids which may be related to his having bilateral vertical rectus muscle surgery after ptosis correction (case 1). All the patients and/or their parents were pleased with their surgery. Two patients saw better and performed better. Case 1 no longer fell over and bumped into things. Case 4 performed better with ball games in the school playground.

\section{Discussion}

We have carried out ptosis surgery in seven patients with ocular fibrosis syndrome. In five patients, a full assessment of their strabismus and its treatment was made before any surgical intervention for the ptosis. Ideally, any extraocular muscle surgery should be completed several months before ptosis surgery is carried out. This is because the position of the lid may be affected by the repositioning or resection of extraocular muscles. Case 1 developed amblyopia despite treatment with occlusion and urgent bilateral brow suspension before strabismus correction was considered necessary. He went on to have bilateral inferior rectus recession 6 months later. He retained a good result for ptosis correction although there was 


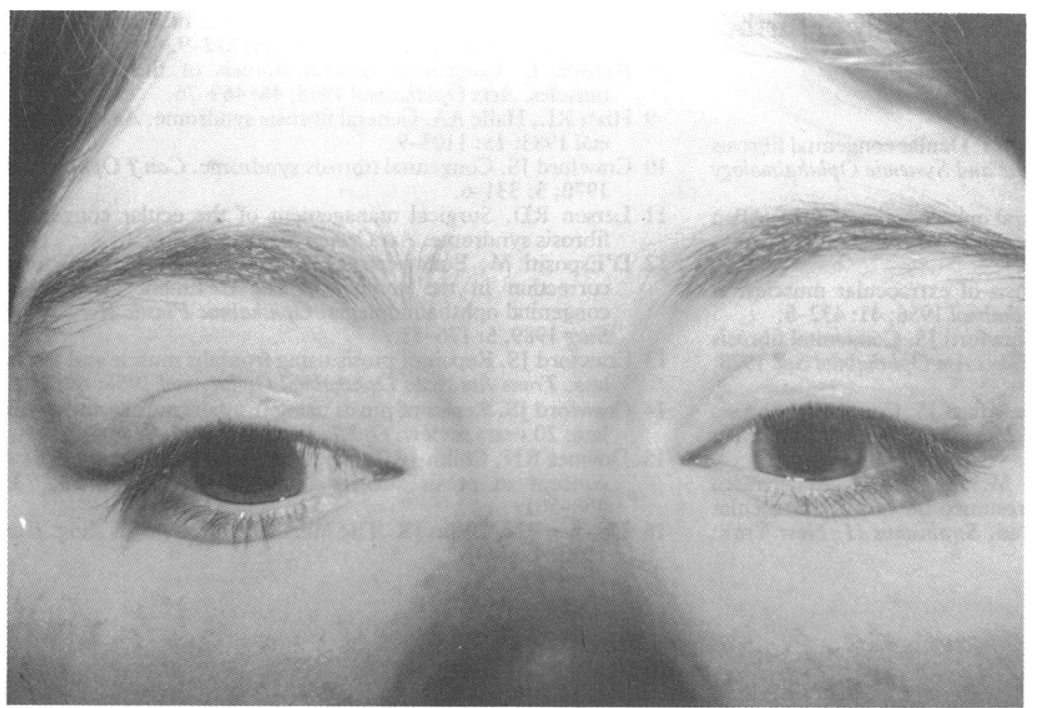

Figure 2 Postoperative photograph of the same patient demonstrating good elevation of both upper lids and reasonable skin creases. The eyebrows are now at a much lower level.

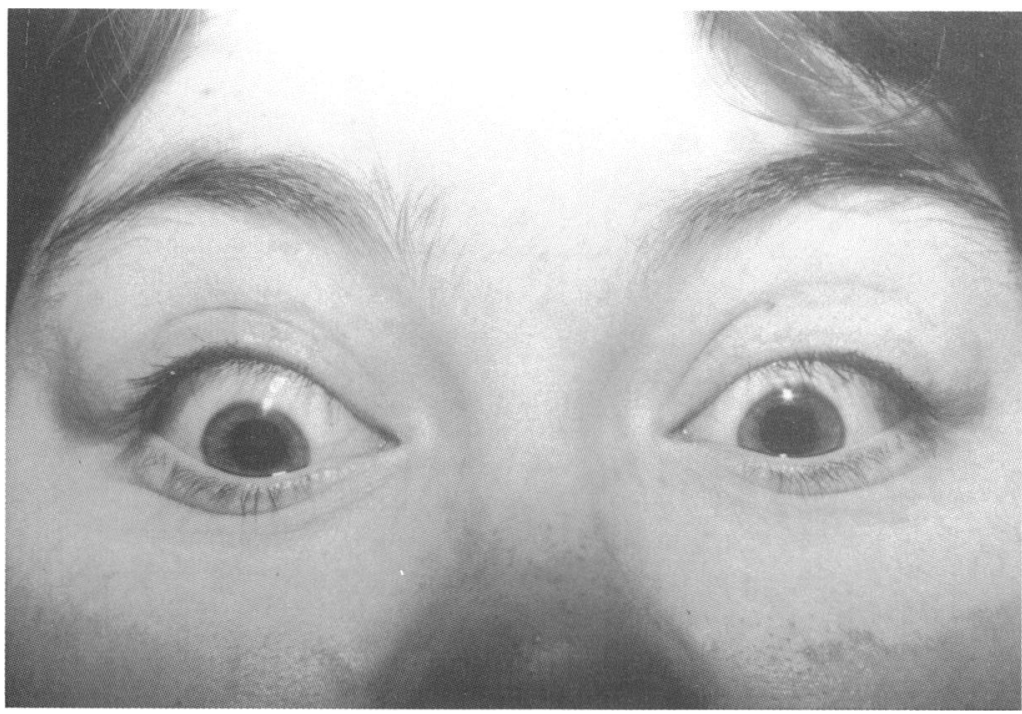

Figure 3 Postoperative photograph of the same patient demonstrating the use of her frontalis muscles to elevate her eyebrows and upper lids while the ocular position remains static due to ocular fibrosis.

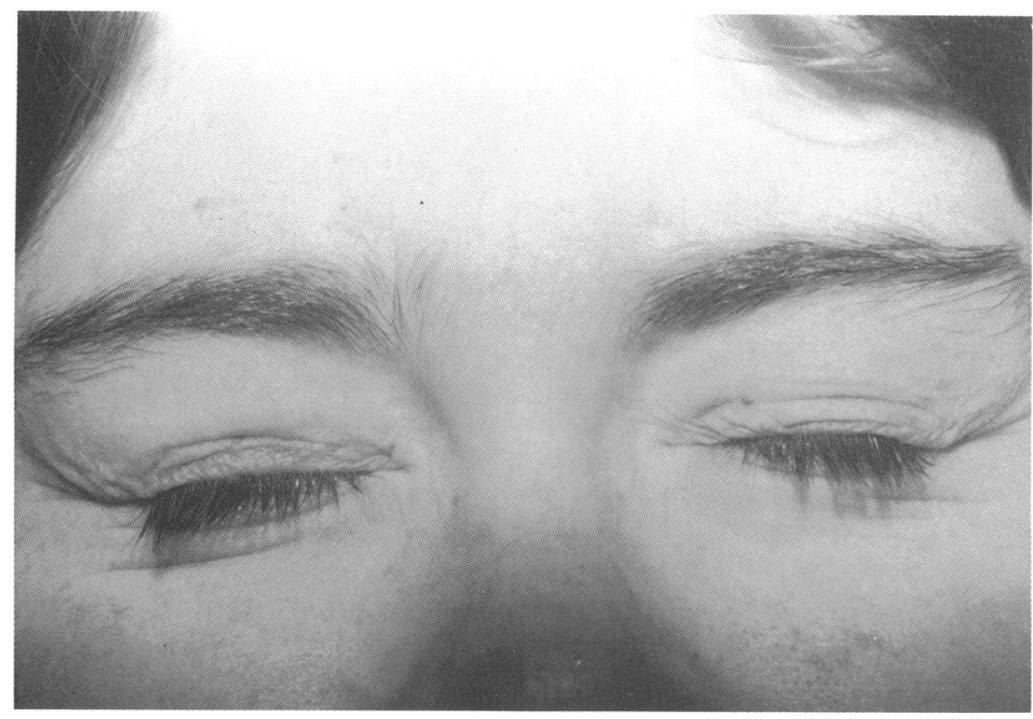

Figure 4 Postoperative photograph of the same patient with both eyes closed demonstrating that eyelid movement is dependent on the eyebrows which are lowered allowing full closure. some lid asymmetry. With case 6 , surgery on the horizontal rectus muscles to correct her exotropia should not affect the lid position afterwards. In patients with ocular fibrosis syndrome, extraocular muscle surgery aims to improve cosmesis and head posture by centring the eyes within the palpebral apertures. Improvement in ocular motility cannot be expected.

The indications for ptosis surgery may be considered under the following groups:

Functional. Urgent ptosis surgery should only be carried out if there is a risk of amblyopia in young children. Very occasionally, this situation may be brought about by surgical correction of hypotropia. Ptosis surgery in older children and in adults may be carried out if vision is compromised despite using maximum tilted head posture. Paediatric patients should be refracted at regular intervals as the incidence of refractive errors is high."

Cosmetic. In adult patients cosmetic surgery is carried out primarily to reduce awkward head posture and create skin creases.

Not every patient with ocular fibrosis syndrome requires ptosis surgery.

Patients with ocular fibrosis syndrome have good frontalis muscle action. ${ }^{17}$ The purpose of brow suspension is to improve the efficiency of the frontalis action in lifting the lids while not limiting eyelid closure. The slings should also create a lid crease thereby improving cosmesis. Levator resection by either an anterior or posterior approach is not thought to be suitable because there is little or no levator function preoperatively. ${ }^{61012}$ Even more importantly, the already fibrosed levator muscle, if resected, would induce lagophthalmos leading to corneal exposure. Our procedure of choice is a Crawford type brow suspension using autogenous fascia lata as first preference. ${ }^{45912-14}$ The use of this autologous material is associated with the least risk of postoperative inflammation, rejection, and necessity for repeat surgery. The size of the leg is more important than the age of the patient in determining whether fascia lata can be harvested. In very small children the leg may not be long enough to allow a substantial graft to be taken and the underlying muscle may also be damaged. If non-autogenous material is required we currently prefer Mersilene mesh. ${ }^{15}{ }^{16}$ Case 1 had bilateral Fox type brow suspensions in 1986 using stored fascia lata as we did not develop the use of Mersilene mesh until 1989. ${ }^{15}$

Corneal exposure is a very real risk with this group of patients. ${ }^{45912}$ There is usually little or no Bell's phenomenon exhibited ${ }^{6}{ }^{12}$ and the hypotropia adds to the problem. Brow suspension has to be carried out cautiously. At the end of the procedure, the position of the lids should be set so that they are just closed on the table with the patient asleep. We believe that this is the maximum amount of surgery that can be done without causing serious problems with corneal exposure. We routinely prescribe tear supplements during the day and an ocular lubricant at night for a period of 2 months postoperatively. If there is minor corneal exposure, these should be continued indefinitely. The upper lid may be dropped surgically if there is a serious problem with exposure. Asymmetry of the upper lid 
positions may also be adjusted by way of further surgery.

1 Nemet.P, Godel V, Ron S, Lazar M. Ocular congenital fibrosis syndrome. Metabolic, Pediatric and Systemic Ophthalmology $1985 ; 8: 172-5$.

2 Brown HW. Congenital structural muscle anomalies. In: Allen JH, ed. Strabismus ophthalmic symposium. St Louis: Mosby, 950: 205.

3 Laughlin RC. Congenital fibrosis of extraocular muscles. A report of six cases. Am 7 Ophthalmol 1956; 41: 432-8.

4 Harley RD, Rodrigues MM, Crawford JS. Congenital fibrosis of the extraocular muscles. Trans Am Ophthalmol Soc 1978 76: $197-226$

5 Harley RD, Rodrigues MM, Crawford IS. Congenital fibrosis of the extraocular muscles. $\mathcal{F}$ Pediatr Ophthalmol Strabismus 1978 . $15: 346-58$.

6 Fells P, Waddell E, Alvares M. Progressive, exaggerated A-pattern strabismus with presumed fibrosis of extraocular muscles. In: Reinecke RD, ed. Strabismus II. New York: Grune and Stratton, 1984
7 Apt L, Axelrod RN. Generalized fibrosis of the extraocular muscles. Am F Ophthalmol 1978; 85: 822-9.

8 Hansen E. Congenital general fibrosis of the extraocular muscles. Acta Ophthalmol 1968; 46: 469-76.

9 Hiatt RL, Halle AA. General fibrosis syndrome. Ann Ophthalmol 1983; 15: 1103-9.

10 Crawford JS. Congenital fibrosis syndrome. Can 7 Ophthalmol 1970; 5: 331-6.

11 Letson RD. Surgical management of the ocular congenital fibrosis syndrome. Am Orthop $\mathcal{F} 1980 ; 30: 97-101$.

12 D'Espositi M Benalo G Magli A Aurilia P. Ptosis correction in the context of the treatment of external congenital ophthalmoplegia. Ophthalmic Plastic Reconstruct Surg 1989; 5: 176-81.

13 Crawford JS. Repair of ptosis using frontalis muscle and fascia lata. Trans Am Acad Ophthalmol Otolaryngol 1956; 60: 672.

14 Crawford JS. Repair of ptosis using frontalis muscle and fascia lata: 20 years review. Ophthalmic Surg 1977; 8: 31-40.

15 Downes RN, Collin JRO. The Mersilene mesh sling - a new concept in ptosis surgery. $\mathrm{Br} \mathcal{F}$ Ophthalmol 1989; 73: concept

16 Downes RN, Collin JR. The Mersilene mesh ptosis sling. Eye 1990; 4: 456-63. 